Chapter 4

\title{
The Effect of Solar Radiation in the Treatment of Swine Biofertilizer from Anaerobic Reactor
}

\author{
Josélia Fernandes Oliveira Tolentino, \\ Fernando Colen, Eduardo Robson Duarte, \\ Anna Christina de Almeida, \\ Keila Gomes Ferreira Colen, \\ Rogério Marcos de Souza and \\ Janderson Tolentino Silveira
}

Additional information is available at the end of the chapter

http://dx.doi.org/10.5772/51946

\section{Introduction}

The intensive process of creating confined pigs generates large amounts of waste, characterized as polluters of great impact to the environment. According to the Brazilian environmental legislation, Law No. 9.605/98, the amount of effluent produced by swine requires appropriate destination, and the producer may be held criminally responsible for damage caused to the environment, human health and animals.

The diet used to feed swine has a high nutritional value, and what is effectively utilized by the animals is approximately $50 \%$ and the remainder is excreted in their feces. In relation to the organic load, the pig manure has a greater power of pollution than the domestic sewage. However, the effluent of these animals contains important chemicals that are necessary in agriculture which, when added to soil, can act as fertilizer, replacing part of chemical fertilizers. However, irrigation with wastewater from pig farms, especially in growing vegetables, generates constant concern about the risks of contamination by pathogenic organisms.

In this sense, the efficiency of a disinfection process to reduce these pathogens in water or wastewater is essential. The disinfection may be performed by chemical and physical processes. In chemical processes what is mainly used are: chlorine gas, sodium hypochlorite, chlorine dioxide and ozone. In the physical processes what is mainly used is the heat and 
light produced by the Sun, specifically ultraviolet radiation. Therefore, in this chapter the aim is to demonstrate the effect of ultraviolet radiation on bacteria and endoparasites present in pig biofertilizer.

\section{Pig industry in Brazil and worldwide}

According to the Brazilian Association of Producers and Exporters of Pork [1], the world production of pork in 2011 was 101.13 million tons. Brazil ranks fourth in the world ranking of production, behind China, European Union and the United States. Another relevant fact is that pork production in Brazil is growing year after year. On the issue of Pork exports, Brazil occupies a prominent position in at fourth place.

The main Brazilian producers are the states: Santa Catarina, Rio Grande do Sul, Parana and Minas Gerais, but the State of Mato Grosso do Sul is who has achieved the highest growth rates [1]. With the increasing swine production, environmental pollution by waste and dejects is a problem that has escalated alarmingly.

Recent assessments have shown a high level of contamination of rivers and surface waters that supply both the rural and urban areas [2]. According to this author, using the concept of equivalent population, a pig, on average is equivalent to 3.5 people in terms of contamination by effluent. The pollutant capacity of a pig is higher than any other species. In other words a farm with a population of 1,000 animals pollutes the environment more than a city of 3,500 inhabitants.

The pig deject is composed of feces, urine, drinking and cleaning waste water, wasted feed, and dust caused by the breeding process [3]. The main causes of sewage pollution by swine effluents is due to its untreated release into waterways, which causes an imbalance due to the reduction of dissolved oxygen in water, the spreading of pathogens and soil and water contamination by nitrates, ammonia and other toxic elements [2].

However, the search for ways to reduce the impact on the environmental, such as the methanogenic fermentation of biodigesters, whose product is rich in nitrogen, phosphorus, potassium and biogas, still continues.[3, 4].

The production of effluents by pig farms has bought great concern due to its high rate of contamination and its large volume as shown in Table 1. Table 2 shows the minimum, average and maximum for the physical-chemical characterization of pig manure obtained in the unity of the waste treatment system of Embrapa (Brazilian Agricultural Research Corporation) in the City of Concord in the State of Santa Catarina - Brazil.

\subsection{Risks of pollution from pig manure}

The improper disposal of pig waste can contaminate surface water with organic matter, nutrients, fecal bacteria and sediment. Nitrates and bacteria are components that affect the quality of underground water systems [2]. 


\begin{tabular}{cccc}
\hline Category & $\begin{array}{c}\text { Manure } \\
(\mathrm{kg} / \text { day })\end{array}$ & $\begin{array}{c}\text { Manure }+ \\
\text { Urine }(\mathrm{kg} / \text { day })\end{array}$ & $\begin{array}{c}\text { Liquid Waste } \\
\text { (Liters/day) }\end{array}$ \\
\hline Pigs $(25-100 \mathrm{~kg})$ & 2,30 & 4,90 & 7,00 \\
\hline Sow gestation & 3,60 & 11,00 & 16,00 \\
\hline Lactating sow + piglets & 6,40 & 18,00 & 27,00 \\
\hline Neck & 3,00 & 6,00 & 9,00 \\
\hline Weaning piglets & 0,35 & 0,95 & 1,40 \\
\hline
\end{tabular}

Table 1. Daily production of pig manure in different production phases Source: Adapted from [4].

\begin{tabular}{cccc}
\hline Parameter $\left(\mathrm{mg.L}^{-1}\right)$ & Low & Medium & High \\
\hline COD & 11.530 & 25.543 & 38.448 \\
\hline Solids & 12.697 & 22.399 & 49.432 \\
\hline Total Volatile Solids & 8.429 & 16.389 & 39.024 \\
\hline Fixed Solids Total & 4.268 & 6.010 & 10.409 \\
\hline Settling Solids & 220 & 429 & 850 \\
\hline Nitrogen Total & 1.660 & 2.374 & 3.710 \\
\hline Phosphorus Total & 320 & 578 & 1.180 \\
\hline
\end{tabular}

Table 2. Physical-chemical characterization of pig manure in Concordia, Santa Catarina Source:[5]

Ceretta et al (2005), studying the importance of runoff as a phenomenon of loss of nitrogen and phosphorus applied through pig slurry in an area cultivated with the rotation oat / corn / turnip, concluded that losses by disposal of nitrogen and phosphorus for the nutrition of plants are considered small, but their concentrations in the major peaks are at risk of eutrophication sources of bodies of water.

Fertilization with excessive or continued swine waste can cause undesirable environmental impacts such as biological and chemical imbalances in the soil, water pollution, loss of productivity and quality of agricultural products and reduce the diversity of plants and soil organisms [8].

The production of pigs can generate other types of pollution such as the odor that occurs due to evaporation of volatile compounds that cause harmful effects to human welfare and animal. The types of airborne contaminants are more common in waste are ammonia, methane, volatile fatty acids, $\mathrm{H}_{2} \mathrm{~S}, \mathrm{~N}_{2} \mathrm{O}$, ethanol, propanol, dimethyl sulfidro sulfidro and carbon. The emission of gases can cause severe damage to the breathing airways of both man and animals, as well as the formation of acid rain through discharges of ammonia in the atmosphere and contribute to global warming $[9,10]$. 


\subsection{Disinfection of waste}

During effluent treatments, the pathogen reduction is essential and this process can be chemic, with the use of disinfectant, or by physical process, destroying or inactivating these agents [11]. The efficient disinfection of the water supply and waste effluent can considerably reduce the transmission of diseases by water [12].

Chlorine is widely used to treat waste water. However, reacting with natural organic matter, this chemical agent generates sub products as chloroform, monochloroacetic acid, trichloroacetic and dichloroacetic. These compounds are considered potentially harmful to human health [13].

It is therefore necessary to develop ways of disinfection without risk to the environment and to humans, while at the same time, maintaining the efficiency provided by chlorine disinfection [14].

Alternative methods of disinfection are being developed in order to replace chemical products, reducing the formation of precursors of trihalomethanes or other byproducts with carcinogenic potential [15].

The use of ultraviolet radiation is an alternative to chemicals in the process of disinfection of drinking water and also wastewater [16], with the advantage of not generating unwanted byproducts and it does not keep waste that could affect the balance of the ecosystem where the effluent is being released [14].

\subsection{Ultraviolet}

Ultraviolet radiation corresponds to the portion of the electromagnetic spectrum which lies between the X-rays and visible light [14]. Ultraviolet radiation can be an alternative to using traditional chemicals in the process of disinfection of drinking water and wastewater [15].

The effect of ultraviolet light on living beings can be divided into UV-A, UV-B, UV-C and UV-vacuum. The UV-A radiation has wavelength between $315 \mathrm{~nm}$ (90.8 kcal / einstein) and $400 \mathrm{~nm}$ (71.5 kcal / einstein). UV-B has a wavelength between $280 \mathrm{~nm}$ (102 kcal / einstein) and $315 \mathrm{~nm}$ (90.8 kcal / einstein). The UV-A radiation is less harmful to humans because has low energy and the "black light" be present. This radiation is used to produce florescence in materials, in phototherapy and artificial tanning [17].

According to Ryer (1997) quoted by [17], UV-B radiation is the most destructive form of light, by having enough energy to cause damage in biological tissues, and the minimum amount that is not completely absorbed in the atmosphere. This radiation is responsible for causing skin cancer.

UV-C has a wavelength ranging from $200 \mathrm{~nm}$ (143 kcal / einstein) at $280 \mathrm{~nm}$ (102 kcal / einstein), is the ultraviolet radiation used as a germicide. The photons of light in this range concentrate significant amounts of energy in collisions with oxygen, resulting in the formation of ozone and are absorbed in a few hundred meters [17]. The range of the wavelength used as a germicide high-power deactivation of microorganism is between $245 \mathrm{~nm}(116.7 \mathrm{kcal} /$ einstein) and $285 \mathrm{~nm}(100.4 \mathrm{kcal} /$ einstein). 
The vacuum-UV radiation has a wavelength 40 to200 $\mathrm{nm}$. The first scientists to report the germicidal effect of sunlight were the British Downes and Blunt in 1877 [18]. Initially, this radiation was used for disinfection of air, pharmaceuticals products and compact stations of drinking water treatment, especially on shipping vessels [14]. The bactericidal effects of UV radiation were proven more accurate form by Barnard and Morgan in 1903, who utilized electrical currents to produce radiation with a wavelength between $226 \mathrm{~nm}$ and $328 \mathrm{~nm}$ [17].

\subsection{Mechanism with ultraviolet disinfection}

The main mechanism of action of ultraviolet radiation in the disinfection process, using the wavelength in sunlight, is by interfering in the biosynthesis and cell reproduction. The microorganisms are inactivated by ultraviolet radiation as a result of photochemical damage caused to nucleic acids, hampering the normal functioning [16, 15].

The UV radiation does not inactivate the microorganisms by chemical reaction, as with most of the disinfecting agents used in water. The inactivation of microorganisms occurs by the absorption of high-energy, which promotes photochemical reactions with the fundamental components of cells, disrupting the mechanism of duplication or killing the same [18].

The ultraviolet disinfection occurs due to absorption of radiation by proteins and nucleic acids DNA and RNA. With the UV absorption of proteins present in the cell membranes there is a rupture of these membranes and consequently cell death. The absorption of low doses of ultraviolet radiation by DNA can just interrupt the reproduction of microorganisms, preventing them from contaminating the environment [15].

Frequently the absorption of ultraviolet light present in the DNA molecules, such as purines and pyrimidines, becomes more reactive. The maximum absorption of ultraviolet radiation by DNA occurs at $260 \mathrm{~nm}$, suggesting that inactivation by radiation is measured by direct absorption of the purine and pyrimidine molecules, leading to the formation of dimers and hydrates [15]. The ultraviolet radiation passes through the cell wall and is absorbed by nucleic acids and to a lesser extent, by the proteins and other molecules that are biologically important [12].

Ultraviolet radiation absorbed by DNA nitrogen bases may result in the formation of pyrimidine dimers. These molecules deform the helical structure of DNA and impair the replication of the nucleic acid. If replication occurs, the new cells will be mutant descendants unable to replicate (WEF, 1995 quoted by [17]. According to Daniel et al. (2001) this is the fundamental mechanism of disinfection by ultraviolet radiation as shown in Figure 1.<smiles>Cc1c[nH]c(=O)[nH]c1=O</smiles>

Thymine<smiles>CC1=CNC(O)NC1=O</smiles>

Thymine

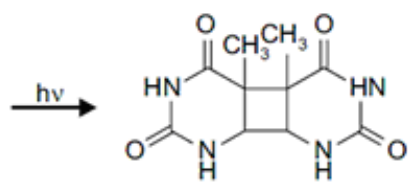

Thymine dimer

Figure 1. Dimerization photochemical thymines of two bases. Source: [14]. 


\subsection{Advantages and disadvantages of ultraviolet}

The advantages of using ultraviolet radiation as a disinfectant agent in water treatment are [14]:

- Ultraviolet radiation is effective for wide range of bacteria and viruses, using relatively small doses;

- Minimum health risks - the formation of byproducts is minimal;

- Gives no residual action, which could react with organic substances in commercial or industrial applications - for example, discoloration is not produced, or a change of flavor, when using ultraviolet radiation in the food industry;

- Safety and acceptance by the operators and the public - no toxic chemical is transported, stored or handled;

- Simplicity and low costs of operation and maintenance - ultraviolet radiation equipment is simpler than the equipment for generating ozone and chlorine dioxide;

- Short contact time, therefore, does not require huge tanks of contact, effective disinfection doses are achieved in a few seconds, compared to the period of 10 to 60 minutes for other disinfecting technologies, being that it is system with an external power source.

Among the disadvantages of disinfection with ultraviolet radiation, are:

- The repair mechanisms of damage DNA caused of microorganisms, if a sub lethal dose is employed;

- The material dissolved or suspended reduces the intensity of radiation as it passes through the water depth;

- It doesn't confer effect to the distributed water because its action is immediate.

However, the fact that ultraviolet radiation does not leave a disinfectant residual in the water has arguably been appointed as an argument for the use of chlorine, because in reality, there is potential for biofilm formation in water distribution networks. If the water contains nutrients (mainly, assimilable organic carbon), these can accumulate around the pipes, supporting microbiological growth and, furthermore, the presence of $1 \mathrm{mg} / \mathrm{L}$ free chlorine residual does not guarantee that the biofilm is not formed on the surfaces of pipes and coliforms at $45^{\circ} \mathrm{C}$ are not found in drinking water [19].

According to Daniel et al. (2001), the disinfection with ultraviolet radiation is most effective for water with a small value of color and turbidity due to the need of light penetration in the center, therefore the quality of water to be treated is an important factor in using this process.

\section{Materials and methodology}

This study was conducted at the Experimental Farm Professor Hamilton Abreu Navarro (FEHAN), Institute of Agricultural Sciences (ICA) of the Federal University of Minas Gerais, Regional Campus Montes Claros / MG. 
The FEHAN is located $7 \mathrm{~km}$ from the city center and has an area of $232 \mathrm{ha}$. Montes Claros is situated at latitude $16^{\circ} 43$ ' $41^{\prime \prime}$ South and longitude $43^{\circ} 52^{\prime} 54^{\prime \prime}$ west (Figure 2). For this municipality, the average altitude is 646 meters in an area of $3568.93 \mathrm{~km} 2$ and a population estimated at 361.9 thousand inhabitants [20].

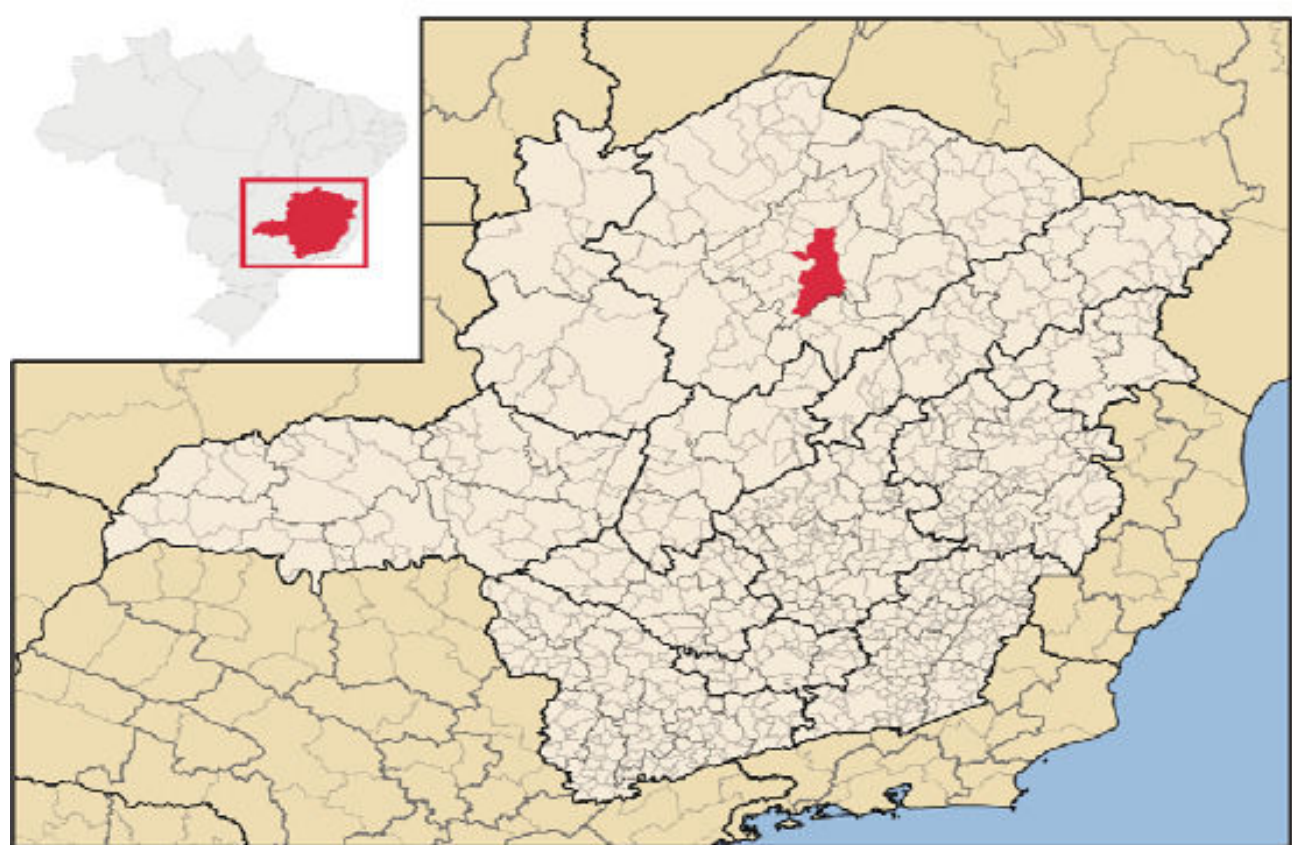

Figure 2. Geographical location of the municipality of Montes Claros - MG; Source: Available at: www.skyscrapercity.com.

At FEHAN, the number of pigs is of 180 animals raised in an intensive production system with complete cycle, i.e., raise, reraise and fatten. The animals are confined to bays, gestation cages and birthing cages. The slaughter age is around six months, weighing on average 100 $\mathrm{kg}$. The animals' diet is based on ground corn, soybean and vitamins / minerals. Water is provided in abundance through troughs in the form of a pacifier.

The cleaning of the swine area happens in the morning with the scraping of excrements and high pressure hose. The effluent is directed by gravity to the digester Indian model with functional load capacity of $17.42 \mathrm{~m}^{3}$ for treatment (Figure 3).

After treatment in the biodigester, for a period of 45 days, samples were collected from 40 liters of effluent and placed in the disinfection device, that we developed, made from recyclable transparent "Pet" bottles, as Figure 4, with the principle of thermosyphon, given the denomination of Ultraviolet Radiation Treatment System (SITRU), the samples were then exposed to ultraviolet radiation for eight consecutive days. The SITRU consists of five columns of 
transparent 2 liter containers of "Pet" each, connected by drainpipes (200 mm) and silicone. Connections are of $32 \mathrm{~mm}$ PVC whose function is to link the five columns of "Pet". A 20 liter container is at the top as a reservoir of effluent, which is connected to SITRU through a pipe of $32 \mathrm{~mm}$ at the top and a pipe of $32 \mathrm{~mm}$ at the bottom, as can be seen in Figure 4 . The SITRU was placed towards the west at an inclination of $30^{\circ}$. The temperatures of the effluent in the ultraviolet treatment system were collected at two periods (Figure 5, Table 3).

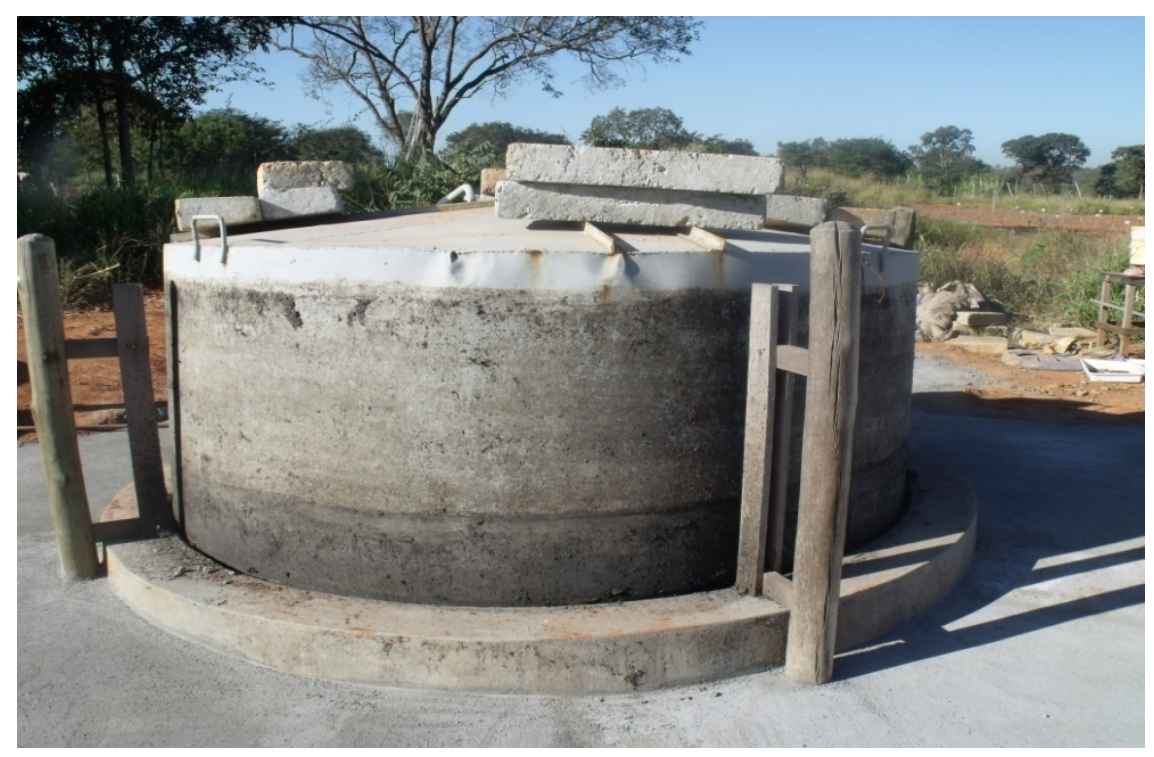

Figure 3. Biodigestor Indian Model.

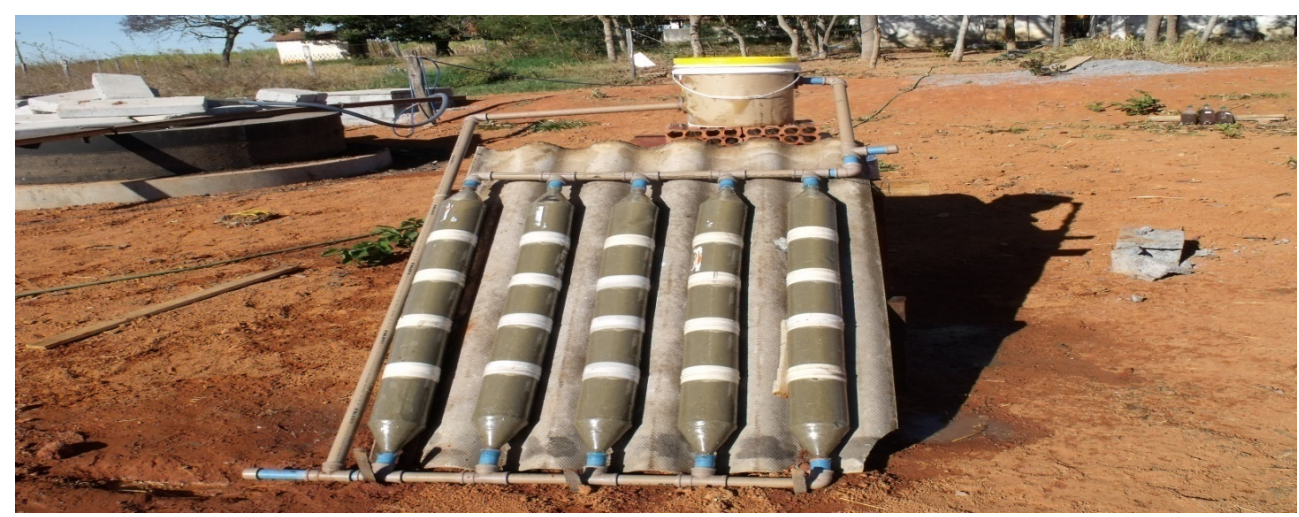

Figure 4. Ultraviolet Radiation Treatment System (SITRU) - Effluent 


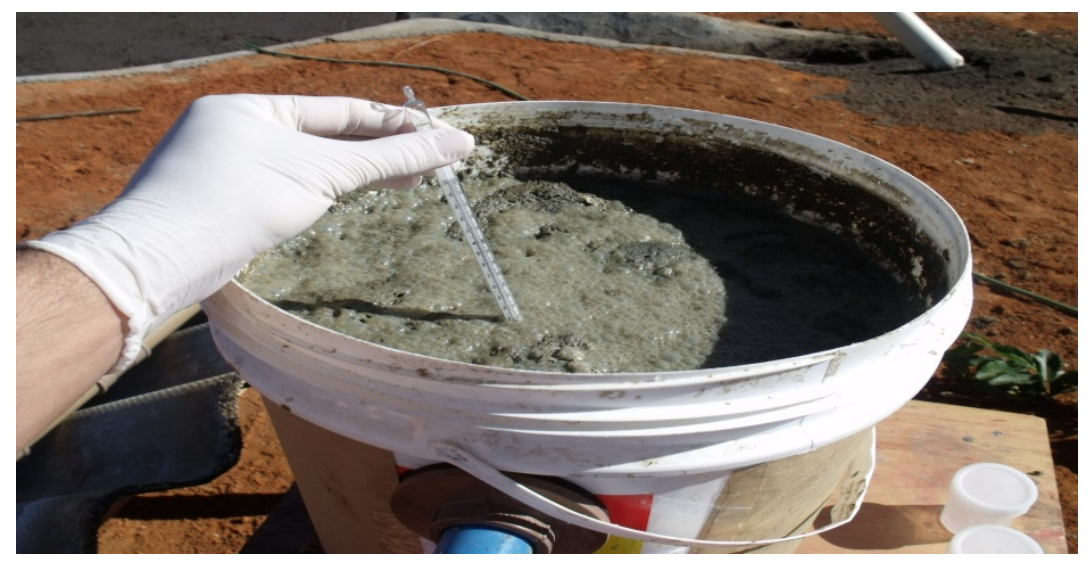

Figure 5. Temperature measurement of the effluent.

The laboratory tests were conducted with the aim of verifying the disinfecting power of solar radiation. Analyzed, the presence of helminth eggs protozoa and oocysts per gram of feces in the biofertilizer in triplicate, at the start of the treatment in the SITRU and at the end of treatment in the SITRU, i.e. parasitological tests were carried out in two stages.

\begin{tabular}{|c|c|c|c|}
\hline Day & Time & Effluent temperature ${ }^{\circ} \mathrm{C}$ & Temperature range $(\Delta t)^{\circ} \mathrm{C}$ \\
\hline $12 / 09 / 2010$ & $15: 00$ & 21 & - \\
\hline $13 / 09 / 2010$ & 9:00 & 18 & \multirow{2}{*}{9} \\
\hline $13 / 09 / 2010$ & $15: 00$ & 27 & \\
\hline $14 / 09 / 2010$ & 9:00 & 19 & \multirow{2}{*}{15} \\
\hline $14 / 09 / 2010$ & $15: 00$ & 34 & \\
\hline $15 / 09 / 2010$ & 9:00 & 20 & \multirow{2}{*}{13} \\
\hline $15 / 09 / 2010$ & $15: 00$ & 33 & \\
\hline $16 / 09 / 2010$ & 9:00 & 20 & \multirow{2}{*}{14} \\
\hline $16 / 09 / 2010$ & $15: 00$ & 34 & \\
\hline $17 / 09 / 2010$ & 9:00 & 19 & \multirow{2}{*}{14} \\
\hline $17 / 09 / 2010$ & $15: 00$ & 33 & \\
\hline $18 / 09 / 2010$ & 9:00 & 20 & \multirow{2}{*}{14} \\
\hline $18 / 09 / 2010$ & $15: 00$ & 34 & \\
\hline 19/09/2010 & 9:00 & 19 & \multirow{2}{*}{14} \\
\hline 19/09/2010 & $15: 00$ & 33 & \\
\hline
\end{tabular}

Table 3. Monitoring the temperature of the effluent in the SITRU reservoir during the days in the field experiment. 


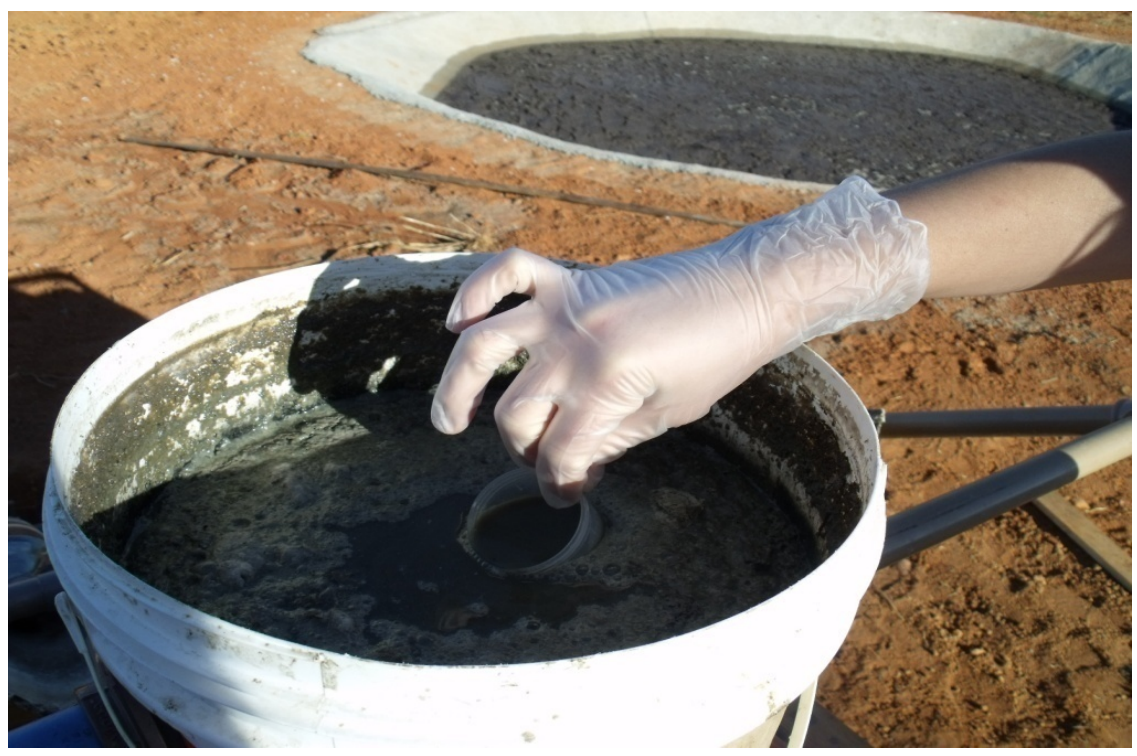

Figure 6. Sample collection for laboratory analysis.

The disinfection efficiency of the biofertilizer by solar radiation was assessed in parasitological and microbiological analyzes in the laboratories of the Institute of Agricultural Sciences UFMG.

Parasitological analyzes were performed at the Parasitological laboratory and the method used was the sedimentation technique for counting eggs per gram of feces / biofertilizer in a Sedgewick Camera for the detection of helminth eggs and protozoan oocysts [21]. In the first stage, the tests evaluated the biofertilizer at the beginning of the treatment in the SITRU; in the second step, analyzes were performed at the end of eight days of treatment in the SITRU. The results of the parasitological analyzes were transformed into $\log (x+1)$ and the means compared the test "t" Student with significance level of 5\%.

Microbiological analyzes were performed in the Microbiology laboratory in accordance with [22] using the method of most probable number (MPN / mL) achieved from the application of the multiple tube technique, which consists in the inoculation of decreasing volumes of sample in a suitable environment for growth of the target organisms, each volume being inoculated in a series of 3 tubes for total coliforms count at $35^{\circ} \mathrm{C}$, fecal coliforms count at $45^{\circ} \mathrm{C}$ and for the identification of $E$. coli in the sample of biofertilizer.

Following APHA (2001), another method used the Agar Mac Conckey. The samples were transferred to plates containing this medium to obtain isolated colonies. Each plate colonies were used for confirmatory biochemical analyzes. The colonies that had characteristics of presumptive E. coli, were analyzed, taking into consideration its aspects. For confirmatory 
biochemical tests, tubes were used, containing Middle Rugai modified with lysine. The collected samples were taken daily in a volume of $200 \mathrm{~mL}$, refrigerated and sent to laboratories. Analyses were performed immediately after collection.

\section{Results and discussion}

Tests of the microbiological samples of disinfection with solar radiation in the SITRU were performed in two steps. In the first step the determination results of the MPN / $\mathrm{ml}$ of total coliforms and fecal coliforms are shown in Table 4. It was not possible to perform the test for E. coli using the NMP / $\mathrm{mL}$, considering that no gas was formed in the pipes of Durham present in the E.C. As shown in Table 4. In the second stage, the research results obtained from E. coli are shown in Table 5.

The samples collected on days 12, 13, 14, 15, 16 and 17 of September 2010, tested positive for E. coli. However, the samples of days 18 and 19 of September 2010 were negative for this microorganism, thereby showing that after seven days of exposure to solar radiation, the treatment system SITRU is effective in the control of E. coli, even though the suspended solids and turbidity values were high.

The ability to resist ultraviolet radiation, for any microorganism, reduces with the increase of applied dose and among microorganisms, even within of the same species; there are large differences in resistance [14]. These results agree with [15] who claims that ultraviolet radiation is more effective in waters with color and turbidity of limited value due to the need of light penetration in the middle. Therefore, the quality of water to be treated is an important factor in using this process.

\begin{tabular}{|c|c|c|c|}
\hline Date & Fecal Samples & $\begin{array}{c}\text { Total Coliforms } \\
\text { Biofertilizer } \\
\text { (MPN / mL) }\end{array}$ & $\begin{array}{c}\text { Fecal Coliforms } \\
\text { or thermotolerant } \\
\text { Biofertilizer } \\
\text { (MPN / mL) }\end{array}$ \\
\hline $12 / 09 / 2010$ & $\mathrm{~A} 1$ & $" />1.100$ & $<3,0$ \\
\hline $13 / 09 / 2010$ & $\mathrm{~A} 2$ & $" />1.100$ & $<3,0$ \\
\hline $14 / 09 / 2010$ & A3 & $" />1.100$ & $<3,0$ \\
\hline $15 / 09 / 2010$ & A4 & $" />1.100$ & $<3,0$ \\
\hline $16 / 09 / 2010$ & A5 & $" />1.100$ & $<3,0$ \\
\hline $17 / 09 / 2010$ & A6 & $" />1.100$ & $<3,0$ \\
\hline 18/09/2010 & A7 & $" />1.100$ & $<3,0$ \\
\hline $19 / 09 / 2010$ & A8 & $" />1.100$ & $<3,0$ \\
\hline
\end{tabular}

Table 4. Results of analyzes of total coliforms, fecal coliforms in the treatment system by solar radiation 


\begin{tabular}{ccc}
\hline Date & Sample & E.coli (Rugai culture medium) \\
\hline $12 / 09 / 2010$ & A1 & Positive \\
\hline $13 / 09 / 2010$ & A2 & Positive \\
\hline $14 / 09 / 2010$ & A3 & Positive \\
\hline $15 / 09 / 2010$ & A4 & Positive \\
\hline $16 / 09 / 2010$ & A5 & Positive \\
\hline $17 / 09 / 2010$ & A6 & Positive \\
\hline $18 / 09 / 2010$ & A7 & Negative \\
\hline $19 / 09 / 2010$ & A8 & Negative
\end{tabular}

Table 5. Results of inactivation of E. coli.

The effect of suspended solids in the efficiency of the disinfection process, which besides increasing absorbance of the effluent, hide bacteria on its inside. Therefore it was recommended a pre-filtration for a better efficiency in disinfection [11].

According to [16], it was possible to observe that a system equipped with a reactor of UV lamps, had a very efficient operation in terms of $E$. coli inactivation for the conditions of the experiments with retention times of 3 and 5 minutes, both in clearer water, as for turbid waters.

The results for the parasitological analysis are presented in Tables 6, 7 and 8 .

\begin{tabular}{ccc}
\hline Sample & Start of treatment & End of treatment \\
\hline A1 & 600 & 600 \\
\hline A2 & 1.400 & 400 \\
\hline A3 & 1.000 & 400 \\
\hline A4 & 1.600 & 400 \\
\hline A5 & 800 & 0 \\
\hline A6 & 2.200 & 200 \\
\hline A7 & 600 & 400 \\
\hline A8 & 1.400 & 1.000 \\
\hline A9 & 1.000 & 600 \\
\hline A10 & 1.600 & 400 \\
\hline A11 & 800 & 400 \\
\hline A12 & 800 & 400 \\
\hline Average & 1150 & 433 \\
\hline Standard deviation & 470 & 239 \\
\hline
\end{tabular}

Table 6. Count of oocyst protozoa count in the effluents of the biodigesters before and after the treatment system by ultraviolet radiation. 


\begin{tabular}{ccc}
\hline Sample & Start of treatment & End of treatment \\
\hline A1 & 600 & 600 \\
\hline A2 & 2.000 & 400 \\
\hline A3 & 1.000 & 400 \\
\hline A4 & 800 & 800 \\
\hline A5 & 800 & 0 \\
\hline A6 & 1.800 & 400 \\
\hline A7 & 1.800 & 400 \\
\hline A8 & 1.800 & 600 \\
\hline A9 & 1.000 & 600 \\
\hline A10 & 800 & 600 \\
\hline A11 & 1.200 & 200 \\
\hline A12 & 400 & 400 \\
\hline Average & 1167 & 450 \\
\hline Standard deviation & 545 & 211 \\
\hline
\end{tabular}

Table 7. Count of eggs of Ascaris sp. in effluents of the biodigestor before and after the treatment system by ultraviolet radiation.

\begin{tabular}{ccc}
\hline Sample & Home treatment & End of treatment \\
\hline A1 & 800 & 0 \\
\hline A2 & 1.000 & 400 \\
\hline A3 & 1.000 & 400 \\
\hline A4 & 1.000 & 0 \\
\hline A5 & 600 & 200 \\
\hline A6 & 800 & 200 \\
\hline A7 & 800 & 400 \\
\hline A8 & 1.000 & 600 \\
\hline A9 & 800 & 200 \\
\hline A10 & 1.000 & 200 \\
\hline A11 & 400 & 200 \\
\hline A12 & 800 & 233 \\
\hline Average & 833 & 187 \\
\hline Standard deviation & 187 & 200 \\
\hline
\end{tabular}

Table 8. Trichostrongylideos egg count of effluents in the biodigester before and after the treatment system by ultraviolet radiation. 
Statistical analysis of data showed that there was no significant reduction, with $5 \%$ significance for the results presented in tables 6, 7 and 8 . However, it may be noted reduction of $62.32 \%, 61.43 \%$ and $72 \%$ of Ascaris sp., protozoa and oocyst trichostrongylideos eggs, respectively, before and after the treatment system by ultraviolet radiation.

According [17], in general, bacteria and viruses are sensitive to ultraviolet radiation, needing only effective doses of $20 \mathrm{mWs} / \mathrm{cm}^{2}$ to inactivate most species. However, the same cannot be reported for protozoa and helminths, endowed with natural protection that allows for their survival in harsh environments. The shapes of the encysted protozoa and helminths eggs are resistant to ultraviolet radiation, requiring extremely high doses and, in most cases, too costly economically to result in efficient inactivation.

During the disinfecting process of biofertilizer in the SITRU, in this present study, it can be observed that the temperature for the experiment ranged between $19{ }^{\circ} \mathrm{C}$ to $34^{\circ} \mathrm{C}$. The thermotolerant coliforms are still alive even at $44{ }^{\circ} \mathrm{C}$ and for the most coliforms best growth occurs to $35{ }^{\circ} \mathrm{C}$, therefore in this study it was observed that the temperature did not influence the reduction of these bacteria.

According to [16], with respect to the analysis in terms of efficiency, it should be noted that the inactivation of E. coli does not determine the safety of the system as a sanitary barrier. For this, it should be the object of verification not only the pathogenic microorganisms of greatest resistance to the process of disinfection by ultraviolet radiation, such as viruses and protozoan cysts, but also those whose dimensions provide a greater protective effect exerted by the particles dispersed in water to the action of ultraviolet radiation. Thus, by establishing a system of disinfection by ultraviolet radiation, it is evident the need to undertake in a comprehensive manner the water's physical-chemical and microbiological characteristics, the dispersed particle size characterization and evaluation of the permanence of these parameters in different seasons of the year.

\section{Conclusion}

Despite the color, turbidity and suspended solids high values, the ultraviolet radiation treatment system - SITRU was efficient in the reducing the presence of Escherichia coli, but less efficiently for Ascaris sp egss, Trichostrongylideos eggs and oocysts protozoa.

\section{Acknowledgements}

Fundação de Amparo à Pesquisa do Estado de Minas Gerais (Fapemig), Conselho Nacional de Desenvolvimento Científico e Tecnológico (CNPq), Banco do Nordeste do Brasil (Fundeci) and Pro-Reitorias de Extensão e Graduação of the Universidade Federal de Minas Gerais for financial support for this research. 


\section{Author details}

Josélia Fernandes Oliveira Tolentino, Fernando Colen*, Eduardo Robson Duarte, Anna Christina de Almeida, Keila Gomes Ferreira Colen, Rogério Marcos de Souza and Janderson Tolentino Silveira

Instituto de Ciências Agrárias da Universidade Federal de Minas Gerais, Montes Claros, Minas Gerais, Brazil

\section{References}

[1] Associação, Brasileira., Da, Indústria., Produtora, E., Exportadora De, Carne., \& Suína-A, B. I. P. E. C. S. (2010). Produção Mundial de Carne Suína. São Paulo, 2010. Disponível em: < http://www.abipecs.org.br/pt/estatisticas/mundial/ producao-2.html>.Acesso em: 13 jun. 2011.

[2] Diesel, R., Miranda, C. R. E., \& Perdomo, C. C. (2002). Coletânea de tecnologias sobre dejetos suínos. Concórdia: BipersBoletim Informativo de Pesquisa Embrapa Suínos e Aves e Extensão, CNPSA/SC e EMATER/RS, n. 10).

[3] Konzen, E. A. (1983). Manejo e utilização dos dejetos de suínos. Co. ncórdia: EMBRAPA/CNPSA, 1983, 36p. (Circular Técnica, 6).

[4] Oliveira, P. A. V. (1993). Manual de manejo e utilização dos dejetos de suínos. Co. ncórdia: EMBRAPA-CNPSA, 1993.188p. (Documentos, 27).

[5] Alves, R. G. C. M. (1996). Tratamento e Valorização de Dejetos da Suinocultura Através de Processos Anaeróbios: operação e avaliação de diversos reatores em escala real. 2007. 170p. Tese (Programa de Pós-Graduação em Engenharia Ambiental). Universidade Federal de Santa Catarina. Santa Catarina, 2007. apud SILVA, F. C. M. Tratamento dos dejetos suínos utilizando lagoas de alta taxa e degradação em batelada. 1996. 115p. Dissertação (Programa de Pós-Graduação em Engenharia Ambiental). Universidade Federal de Santa Catarina, Florianópolis, 1996.

[6] Oliveira, P. A. V. (2004). Tecnologias para o manejo de resíduos na produção de suínos: manual de boas práticas. Con. córdia: Embrapa Suínos e Aves, 2004. 109p.

[7] Ceretta, C. A., Basso, C. J., Vieira, F. C. B., Herbes, M. G., Moreira, I. C. L., \& Berwanger, A. L. (2005). Desejo líquido de suínos: I- perdas de nitrogênio e fósforo na solução escoada na superfície do solo, sob plantio direto. Revista Ciência Rural, Santa Maria, n.36, nov-dez, 2005., 35, 1296.

[8] Seganfredo, M. A. (2006). Viabilidade econômico-ambiental do uso de dejetos animais e lodos de esgoto como fertilizante. Palestra apresentada na Fertbio 2006. Bonito, MS, 2006. 
[9] Perdomo, C. C. (1999). Sugestões para o manejo, tratamento e utilização de dejetos suínos. Concórdia: EMBRAPA/CNPSA, 1999.1p.

[10] Lucas, J., Santos, T. M. B., \& Oliveira, R. A. (1999). Possibilidade de uso de dejetos no meio rural. In: WORKSHOP: mudanças climáticas globais e a agropecuária brasileira, Campinas. Memória. Embrapa Meio Ambiente, 1999. , 1, 42.

[11] Camacho, P. R. R. (1995). Desinfecção de efluentes de sistemas de tratamento de esgotos sanitários por meio da radiação ultravioleta. 1995. 94f. Dissertação (Mestrado em Concentração em Tecnologia Nuclear Básica)- Instituto de Pesquisas Energéticas e Nucleares (IPEN), Autarquia Associada à Universidade de São Paulo, São Paulo, 1995.

[12] Daniel, L. A., \& Campos, J. R. (1992). Fundamentos e aspectos de projetos de sistemas de desinfecção de esgoto sanitário com radiação ultravioleta. Revista DAE. São Paulo, n. 7, jan/fev. 1992., 163, 5-11.

[13] Brasil, Fundação Nacional de Saúde.(2007). Potenciais fatores de risco à saúde decorrentes da presença de subprodutos de cloração na água utilizada para consumo humano. Brasília: Funasa, 2007. 126p. Disponível em: http://www.funasa.gov.br/ internet/arquivos/biblioteca/potFatores.pdf.Acesso em: 14 de jun. 2012

[14] Daniel, L. A. (1989). Desinfecção de efluentes de esgoto sanitário pré-decantado empregando radiação ultravioleta. 1989. 124 f. Dissertação (Mestrado em Engenharia Civil EESC-USP)- Universidade de São Paulo, São Paulo, 1989.

[15] Daniel, L. A., et al. (2001). Processos de desinfecção e desinfetantes alternativos na produção de água potável. São. Carlos, São Paulo: PROSAB, 2001. 139 p.

[16] Aguiar, A. M. S. (2000). Avaliação do emprego da radiação ultravioleta na desinfecção de águas com cor e turbidez moderada. Dissertação. (Mestrado em Saneamento, Meio Ambiente e Recursos Hídricos)- Universidade Federal de Minas Gerais, Belo Horizonte, 2000, 114f.

[17] Gonçalves, R. F. (2003). Desinfecção de efluentes sanitários. Vitória, ES: Projeto PRO$\mathrm{SAB}, 2003.438 \mathrm{p}$.

[18] Koller, L. R. (1952). Ultraviolet radiation. New York: John Wiley \& Sons, 1952. 270 p.

[19] Souza, J. B. (2000). Desinfecção de águas com cor e turbidez elevadas: comparação técnica de processos alternativos ao cloro empregando radiação ultravioleta e ácido peracético. 2000, 147p. Dissertação (Mestrado em Hidráulica e Saneamento)- Escola de Engenharia de São Carlos, Universidade de São Paulo, São Carlos, 2000.

[20] USEPA.(1999). Alternative desinfectants and oxidants. Guidance Manual, EPA 815R-99-014. Cap. 8, , 8.

[21] Instituto, Brasileiro., De Geografia, E., \& Estatística, . I. B. G. E. (2010). Disponível em: <http://www.ibge.gov.br/cidadesat/topwindow.htm?1>.Acesso em: 20 jun. 2011. 
[22] Urquhart, G. M., et al. (1996). Parasitologia veterinária. 2. ed. Rio de Janeiro, Rio de Janeiro: Guanabara Koogan, 1996.

[23] American Public Health Association- APHA.(2001). Compendium of methods for the microbiological examination of foods. ed. Washington: APHA, 2001, 676 p. 
